\title{
Secular stagnation and progressive economic policy alternatives
}

\author{
Özlem Onaran* \\ Professor of Economics and Director, Greenwich Political Economy Research Centre, University of Greenwich, \\ London, UK
}

This paper summarizes two main findings in the post-Keynesian literature regarding the linkages between financialization, income distribution, accumulation and productivity. First, at the core of secular stagnation lies the missing link between profits and investment. Second, rising inequality and financialization have been the main reasons for this missing link and hence the major brakes against capital accumulation and growth. The paper concludes with alternative progressive policies based on a coordinated policy mix of equality-led development and public investment.

Keywords: wage share, wage-led growth, globalization, public investment

JEL codes: E12, E22, E25

\section{INTRODUCTION}

The world is likely to be entering the third phase of the Great Recession, with a risk of a further decline of already-low growth to near stagnation, particularly if global demand decreases further as prospects weaken for emerging economies. In the first two phases, the crisis spread from the US to the eurozone, and capital flew to emerging economies fuelled by cheap central bank lending in the core. At this third new phase, this emerging market bubble is about to burst. The emerging economies have been the locomotive of growth in the global economy in the aftermath of the Great Recession; and now we are facing the fact that China and other emerging economies can no longer be the drivers of growth in the G7. The advanced economies in the meantime have done very little to change the fundamentals of their flawed economic growth model, which were the root causes of the Great Recession.

Building on the post-Keynesian literature, this paper argues that at the root of this new normal of slow and volatile growth rates in the world economy, dubbed as secular stagnation, lies the vicious circle of rising inequality, financialization, chronically low demand, slower accumulation and productivity increases, and low growth and fewer or bad quality jobs.

Section 2 presents the linkages between financialization, income distribution, accumulation and productivity. Section 3 presents alternative progressive policies based on a coordinated policy mix of equality-led development and public investment. Section 4 concludes.

* Email: o.onaran@gre.ac.uk. Earlier versions of this work have benefited from comments by Yannis Dafermos and Andrew Watt. All remaining errors are mine. 


\section{FINANCIALIZATION, DISTRIBUTION, ACCUMULATION AND PRODUCTIVITY}

The slowdown in growth rates along with higher volatility is not a new phenomenon; this is a trend observed in all the advanced capitalist countries, as well as some emerging economies in Latin America or for instance Turkey, since the rise of neoliberalism (Onaran/ Galanis 2014). At the core of this development lies the missing link between profits and investment. Rising inequality and financialization have been the main reasons behind this missing link and hence the major brakes on capital accumulation and growth.

Epstein (2005: 1) defines financialization as the increasing importance of financial markets, financial motives, and financial institutions, and financial elites in the operation of the economy and its governing institutions, both at the national and international level'. There is evidence of negative impacts of expanding financial sector on income distribution and demand (Onaran et al. 2011; Hein 2013; Stockhammer 2016), and in particular on investment (Stockhammer 2004; 2006; Hein/van Treeck 2008; Orhangazi 2008; van Treeck 2008; Dallery 2009; Cordonnier/Van de Velde 2015).

Despite increasing profits, private investment remained weak in the advanced economies as firms directed their profits to financial speculation (Stockhammer 2006; Orhangazi 2008; van Treeck 2008; Tori/Onaran 2015; 2016). According to research on the investment behaviour of non-financial corporations in the US, the UK and the EU15, not only high dividend payments but also increasing financial revenues of firms due to their surging financial activities crowd out private investment in physical machinery and equipment (Orhangazi 2008; Tori/Onaran 2015; 2016). Perversely, financial activities do not provide more funds for productive activity in the case of large companies. ${ }^{1}$ Rotta (2015) defines a broader category of unproductive accumulation from a Marxist perspective, including not only finance but also activities based on knowledge rents, and finds that unproductive accumulation has occurred systematically at a faster pace than productive accumulation in the US in the postwar period, and productive and unproductive forms of accumulation do not share a common trend or a stable long-run equilibrium relationship.

Financialization and its effect on corporate strategies have also had detrimental effects on the bargaining power of labour (Hein/van Treeck 2008; Hein/Mundt 2012; Stockhammer 2016). On the one hand, the orientation towards shareholder value increased the dominance of shareholders' demands over workers' demands. On the other hand, increased domestic and global financial investment opportunities increased the fall-back options of non-financial firms both in terms of geographic location as well as financial assets, putting pressure on domestic and irreversible real investment in physical machinery and capital.

Financialization and increased fall-back options of capital, in particular with respect to tax competition between different jurisdictions, have also had effects on the composition of public spending and taxation (Onaran/Bösch 2014), which in turn has contributed to the decline in the bargaining power of labour.

These developments went along with further institutional and structural changes that led to a significant fall in trade union density and collective bargaining coverage (Onaran et al. 2015). As a result, in the last three and a half decades, inequality has increased substantially and the share of national income that goes to wages has fallen dramatically across the world (Onaran/Galanis 2014; Stockhammer 2016).

1. The results are more nuanced in the case of small enterprises that are facing more substantial credit constraints and thereby rely on internal funds (Orhangazi 2008; Tori/Onaran 2015; 2016). 
Figure 1 parts (a) and (b) show the developments in the share of wages in national income (labour compensation, adjusted for the labour income of the self employed, as a ratio to GDP at factor cost) along with the rate of growth of GDP in the US and the 15 Western European Member States of the EU (the EU15). The share of wages in the US GDP fell from 68.1 per cent in 1974 to 63.0 per cent in 2007, just before the Great Recession. During the Great Recession and in its aftermath, the wage share continued to decline by another 2.8 percentage points during 2009-2013, after which it stabilized. During normal recessions, the wage share in the advanced capitalist countries is countercyclical, as productivity (output per employee) falls but real wages do not fall or at least not proportionately. The Great Recession has defied this general trend with the wage share continuing to fall during the recession as well as during the recovery. At the same time the growth rate has been significantly lower and more volatile, with an average annual

\section{(a) The US}



(b) The EU15

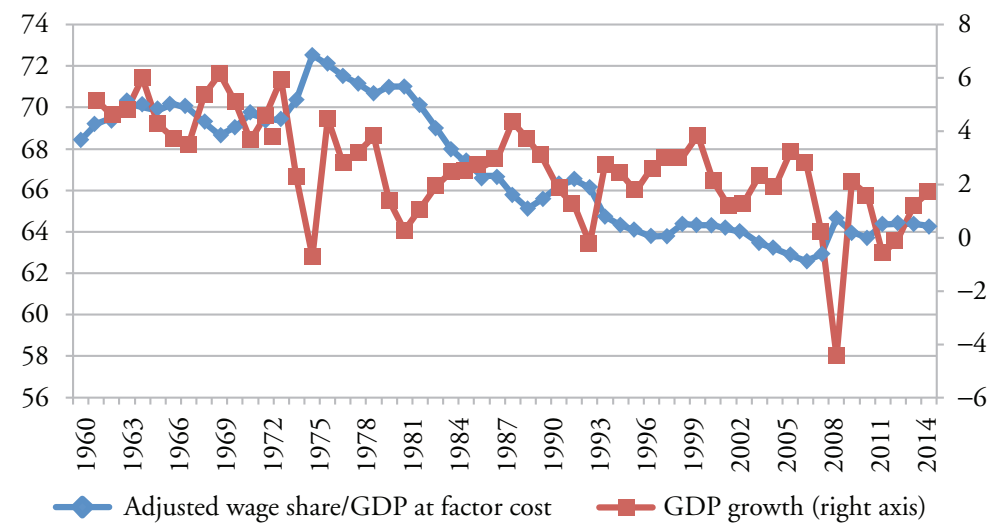

Note: Labour compensation adjusted for the labour income of the self employed as a ratio to GDP at factor cost; 2014 and 2015 are provisional data.

Source: AMECO.

Figure 1 The share of wages in GDP and growth of GDP, 1960-2015 
growth of 2.8 per cent in the US during 1975-2015, compared with 4.0 per cent annual growth during 1961-1974. In Europe (the EU15), the share of wages declined from 72.8 per cent in 1975 at their peak to 62.6 per cent in 2007 . While in the early years of the recession, the wage share in the EU15 increased slightly, there was a 1 percentagepoint fall during 2009-2011, since when the wage share has been stagnant. Growth performance of the EU15 has been similarly disappointing along with the secular fall in the wage share: average annual growth has fallen from 4.7 per cent during 1961-1974 to 1.9 per cent during 1960-1974.

Wage stagnation has fuelled increasing profits as a share of GDP, but this has led to bleak prospects in terms of demand. While this is a puzzle from a neoclassical point of view, it is not unexpected for post-Keynesian/Kaleckian economics, which highlight the dual role of wages as both a cost item and source of demand. Econometric findings in the post-Kaleckian research tradition shows that a lower share of wages in national income leads to a lower GDP in most large countries (Stockhammer/Onaran 2004; Onaran/Stockhammer 2005; Naastepad/Storm 2006-2007; Hein/Vogel 2008; Onaran/Galanis 2014; Onaran/Obst 2015). The negative impact is amplified when wage stagnation policies are imposed in an integrated region such as the EU via the European Commission policies (EC 2006; 2013) or globally in the context of a global race to the bottom in labour share (Stockhammer et al. 2009; Onaran/Galanis 2014; Onaran/Obst 2015).

Hence the demand regime is, as it is termed, 'wage-led' in the majority of the large countries and in large economic regions such as the EU or globally. On the one hand, a pro-capital redistribution of income leads to lower domestic consumption demand. On the other hand, the stimulus to private investment due to higher profits remains weak, if there is one at all, and at the same time private investment responds strongly to the fall in demand. Onaran/Obst (2015) show that, despite increasing profit share in GDP, private investment decreased in the majority of the EU15 countries due to the substantially negative impact of the simultaneous fall in the wage share on demand across the EU15. Firms directing their profits to financial speculation in the absence of a healthy growth in demand is a result of this process as much as it contributes to the lack of demand. The much celebrated impact of wage stagnation on external demand that is, higher net exports - is rather weak in the case of large, relatively closed economies, and the impact is diminished substantially when all countries implement the same international competitiveness policies based on labour market flexibility and cuts to labour costs (Onaran/Galanis 2014; Onaran/Obst 2015). This leaves countries with the net negative impact of rising inequality on domestic demand, that is, the sum of the effects on domestic consumption and private investment. Moreover, some small countries, which have profit-led demand regimes - that is, countries that grow faster along with an increasing profit share (a falling wage share) if they are the only country experiencing this shift in income distribution - also start experiencing lower demand and growth when their trade partners also implement similar wage moderation policies. Austria and Ireland in the EU15 and Canada, Mexico and Argentina globally are such examples (see Onaran/ Obst 2015 for the EU15; Onaran/Galanis 2014 for the G20).

In other words there is a fallacy of composition both at the national level between the rationale of the firm vs the aggregate economy, and at the global level between the national rationale of a small economy vs the global economy. Although a high share of export openness increases the importance of international markets and the likelihood of a small economy being profit-led in isolation, increased contagion of similar wage moderation policies in the age of globalization decreases the impact of such policies on the competitiveness of each country, and makes them individually and collectively more likely to be wage-led. 
The finding that inequality deters growth is no longer confined to heterodox research; there is an increasing amount of research being produced at the IMF and the OECD (for example, Berg et al. 2012; Foerster/Cingano 2014), which justifies the negative effects mostly by supply-side factors such as barriers to human capital accumulation. Unfortunately, the demand-side effects of inequality are still neglected in these mainstream analyses. The main source of inspiration in this research is the new institutionalist political economy with its neoclassical origins, which highlights higher political instability and uncertainty (Alesina/Perotti 1996); increased risk of popular support for redistribution and higher capital taxes with negative consequences for investment (Alesina/Rodrik 1994; Persson/Tabellini 1994); and the negative effects of credit market imperfections on human capital accumulation (Galor/Zeira 1993). Most recently, a study by the IMF (Decressin et al. 2015) has also analysed the impact of a simultaneous decline in wages in all the eurozone countries, and finds a negative effect on the GDP of the eurozone as a whole, thus confirming one of the core results in the post-Kaleckian literature (Onaran/Obst 2015): a simultaneous decline in the wage share in all EU15 countries eliminates the positive competitiveness effects on net exports, and leads to overall negative impact on growth.

In the aftermath of the Great Recession, the lack of a full recovery in wage income continues to be a drag on household confidence and demand, which in turn discourages business investment in the absence of a healthy growth in domestic demand. In the past, countries such as the US, the UK, Spain and Ireland, or emerging economies such as Turkey and South Africa, relied on household debt to maintain consumption levels in the absence of a healthy growth in their wages and salaries. The mirror image of this debt-driven growth model was the export-led growth model of Germany and Austria, or Japan or China in the periphery, where countries tried to export their way out of the problem of deficiency of domestic demand faced with a declining wage share. After the crisis, recovery in many countries with the debt-driven model, such as the UK, is still based on the same shaky grounds, as it is driven by a massive increase in private household debt and will remain fragile to any increase in interest rates in the future. Just as before the Great Recession, working people are obliged to rely on debt to maintain their living standards. The rise in inequality and stagnation in wages have been two of the fundamental flaws in the neoliberal economic model, which have been at the root of the Great Recession, and we are far from correcting this imbalance.

Finally, in the absence of strong investment performance and stagnant demand, it is no wonder that the world is in a phase of low productivity and low potential growth. Productivity has two components. One is simply related to demand, as actual output is demand-driven. The other is about potential productivity, which is determined by technological progress, which is related to both investment and wage costs. Investment responds to demand; lower wages not only lead to lower demand and affect investment through the demand channel, but also make firms less reluctant to invest due to a tendency to exploit low labour costs. Overall, the mixture of financialization and rising inequality has created an increasingly fragile mode of capitalist production with volatile demand and stagnant productivity.

\section{THE CASE FOR A COORDINATED POLICY MIX OF EQUALITY-LED DEVELOPMENT AND PUBLIC INVESTMENT}

A strong recovery with decent jobs as opposed to fragile debt-driven growth requires a strong recovery in wages embedded in a broader macroeconomic and industrial policy, financial regulation and corporate governance framework. Only then will investment and productivity follow. 
In this section we first summarize a policy scenario that begins to reverse the decline in the wage share along with a concerted increase in public investment in social and physical infrastructure. ${ }^{2}$ The scenario is based on a coordinated mix of policies in the G20 targeted to increase the share of wages in GDP over the next 5 years by 1 per cent to 5 per cent depending on the country, and to raise public investment in social and physical infrastructure by 1 per cent of GDP in each country. Building on the econometric estimations by Onaran/Galanis (2014), the impact of the increase in the wage share on growth varies in different countries according to the structure of their economies, notably their investment and their export and import shares. Therefore the proposed policy mix takes into account these differences and proposes differential increases in the wage share in different groups of countries. Countries are subdivided into three groups, starting with countries where growth is predominantly wage-led, including the euro area, the UK, the US, Japan, Turkey and Korea. Increasing the share of wages in GDP by 5 percentage points in these countries could result in a wage-led recovery offsetting any negative effects on net exports or private investment. The second group includes Canada, Mexico, Argentina and India, where the wage share could be increased by 3 per cent of GDP. While growth in these countries when they are treated in isolation is profit-led (that is, a higher profit share and a lower wage share leads to higher growth), a simultaneous increase in the wage share in the G20 (even at an equivalent amount in all countries) would lead to higher growth in these countries as well. Finally, in the third group, a modest increase in the wage share by 1 per cent of GDP in China, South Africa and Australia can be pursued as part of a coordinated policy package.

In a scenario of coordinated wage-led recovery, all countries can increase their growth and overall this wage-led recovery could create about 2 per cent higher GDP in the G20 as a whole at the end of 5 years.

The effect of a coordinated public investment stimulus - that is, increasing the ratio of public investment in physical and social infrastructure to GDP by 1 per cent in each country - is simulated under different assumptions about the size of multipliers. ${ }^{3}$ The growth effects of a simultaneous public investment stimulus are significantly higher than those of an isolated stimulus in one single country, since the former involves cross-country interactions, that is, international demand spillovers. The results show that a public investment stimulus of 1 per cent of GDP in each country can lead to about 2-4 per cent higher GDP in the G20 - compared to business as usual.

Finally, the results show that a policy mix of coordinated wage increases and public investment stimulus can lead to higher GDP in the G20 by 3.9 per cent under the assumption of the lowest multiplier of $0.5 ; 4.4$ per cent under the assumption of a multiplier of 1.22; 5.5 per cent under the assumption of a multiplier of 1.8; 5.8 per cent under the assumption of our country-specific multipliers.

2. This simulation is based on Onaran (2014) prepared for the L20 policy statement at the G20 meeting in 2014, convened by the International Trade Union Confederation (ITUC) and Trade Union Advisory Committee (TUAC) to the OECD. A more detailed discussion of the simulation results is forthcoming in Onaran (2016b).

3. One scenario uses the country-specific multipliers identified in Onaran/Galanis (2014). The second scenario assumes the multiplier to be 1.22 in all countries. This multiplier value is based on the mean of a large sample of multiplier values for public investment based on the literature, which has been reviewed by Gechert (2013). Gechert (ibid.) reports the mean of 98 studies published between 1992 and 2013, providing a sample of 1882 observations of multiplier values for public investment. The last two simulations are based on the assumption of a high value multiplier, 1.8, and a low value multiplier, 0.5, as used by the International Monetary Fund (IMF 2009) regarding the values of capital spending multipliers. 
In summary, a policy mix of raising the wage share (for example, through a rise in minimum wages, or changes in labour market and trade union and collective bargaining legislation) together with increased public investment in social and physical infrastructure would give a significant stimulus to growth and hence employment over a 5-year period in G20 countries.

The rise in the wage share may lead to deterioration in the trade balance, depending on the labour intensity of exports, pass-through from labour costs to prices, and the price elasticity of exports and imports. However, the second component of the policy mix raises public investment, which will not only stimulate growth in the short term but would also, in the medium term, lead to higher investment and productivity, and a more diversified economic structure, changing the structure of their exports towards less labourintensive goods as well as goods with a lower price elasticity of demand.

The concerns regarding the inflationary effects of wage increases are also not supported by empirical evidence. In particular, as some advanced countries are at the borders of deflation, policies to align wage increases with the historical increases in productivity in the past will only help to reach the inflation target, while at the same time helping to generate a wage-led recovery and decent job creation. Onaran/Obst (2015) estimate the impact of a coordinated increase in the wage share in the EU15 by 1 percentage point per year, and find that this will lead to only a modest 1.2 percentage-point annual increase in inflation in the EU15. This alternative scenario would be consistent with an annual nominal wage increase of 3.1 per cent in the EU15 on average (ibid.).

These simulation results do not take into account the potential long-term impact of these changes on productivity, employment and income distribution. A decrease in unemployment could potentially feed back into income distribution, and lead to an increase in the wage share. If the profit share falls below a critical level, this in turn can increase the sensitivity of private investment to profits, and decrease its sensitivity to demand (Onaran 2016a). However, if incomes policy mediates the impact of growth on distribution once a decent income distribution between wages and profits is achieved, and if public investment continues to stabilize demand and private investment, such feedback effects from growth to a profit squeeze and lower private investment can be minimized. Moreover, the simulation results above ignore the potential crowding-in effects of public investment on private investment due to a change in business environment and the productivity of the labour force; the more important these effects are, the higher will be the multiplier impact of public investment on growth.

Coordination of wage policies at the European and global level is crucial to ensure that wages increase in line with historical increases in productivity to stabilize effective demand, to avoid counterproductive beggar-thy-neighbour policies, and to prevent a race to the bottom. In the euro area, this implies that wage policy has to take into account current-account surpluses as much as deficits, and coordination must aim at avoiding a deflationary adjustment with substantially higher wage growth in the surplus countries, while also aiming at convergence in productivity through active investment policies (Onaran/Stockhammer 2016).

The empirical research results summarized above indicate that Europe is the main beneficiary of a concerted rise in the wage share across the world; therefore it should and can take the lead to coordinate high-road labour market policies as opposed to its current practice of leading and imposing wage stagnation. Globalization is not a barrier to implementing wage-led growth policies in Europe as it is a wage-led region even in isolation; however, if such policies are spread to the rest of the world, the room for manoeuvre and the economic significance of the impact increase substantially.

A reversal of low-road labour market policies and associated wage stagnation driven by large wage-led economies such as the EU will help to create a new development model and 
space for a domestic-demand-oriented and more egalitarian growth model in the developing countries as an alternative to export-led growth. The results also indicate the importance of developing South-South cooperation such that the internal market the developing countries can target can be larger, increasing the likelihood of success for wage-led development policies.

A wage-led development strategy requires policies targeting the top, middle and bottom of the wage distribution (Onaran 2015). This in turn requires the use of both predistributive and redistributive policies.

Predistributive policies can aim at improving the market distribution of income by a variety of policies to build institutions and re-regulate the labour market, to improve trade union legislation, and to increase the coverage of collective bargaining, which will increase the bargaining power of labour. Improving the union legislation alone could take us a long way: according to simulation results by Onaran et al. (2015) for the case of the UK, if the trade union density were to increase back to its 1980 level, when half of the employees were members of a trade union (as opposed to the current level of union density of 25 per cent), the share of wages in national income could increase by up to 9 percentage points, and GDP per capita in the UK could increase by $£ 444$ (or 1.6 per cent).

Regarding the bottom of the wage distribution, the key priority is establishing a sufficiently high statutory minimum wage to address the growth of in-work poverty. Evidence shows that robust minimum wages can reduce inequality (ILO 2012). A rise in minimum wages not only reduces reliance on benefits, but also improves demand and growth in a wage-led economy (Onaran 2015). Low-income earners would spend a higher proportion of their income, and this would lead to a further increase in growth and employment through the multiplier effect. Raising the minimum wage can also increase labour force participation rates, as paid employment becomes attractive, and reduce spending on unemployment benefits by the state. The reference point for the statutory minimum wage has to be a living wage.

The higher end of the wage distribution must be regulated as well. This would increase the scope to increase wages at the bottom and the middle, while offsetting the squeeze on profits by cutting high managerial wages (Onaran 2015). The current squeeze of profits by managerial wages neither creates sufficient demand, as the rich also have a very low marginal propensity to consume, nor helps productivity increases. The recent crisis has made it clearer that top executive pay has been fundamentally unrelated to firm performance in the financial industry; the problem with top pay is not limited to banks but is widespread among large companies in the private sector. Corporate governance reforms should aim at curtailing top managerial compensation via limiting the ratio of top pay to median incomes in the private sector, while also enforcing the payment of a minimum of a living wage at the bottom end of the scale.

A wage-led growth regime can be seen broadly as an equality-led growth regime, embracing all dimensions of equality. Eliminating gender wage gaps as part of a process of an upward convergence in wages and eliminating discriminatory labour market practices will contribute to greater equality and overall a higher wage share, which, in turn, in a wage-led economy such as Europe, will lead to higher growth (Onaran 2016b).

These predistributive policies should be accompanied by redistributive policies both to decrease inequality and to tame the power of capital. This requires a rise in corporate and wealth tax rates as well as top marginal income tax rates. We need to restore the progressivity of the tax system. Progressive income tax could be used to impose a maximum income, with the highest marginal tax rate increasing to 90-95 per cent above a threshold corresponding to the top 1 per cent of incomes. In the UK, between 1974 and 1979, the top income tax rate in the UK was 83 per cent on incomes above approximately $£ 91000$ in today's prices ( $£ 24000$ at 1979's; Onaran 2015). Another possibility is suggested by 
Goda et al. (2016) to link top income and wealth taxes to median incomes and median wealth holdings, for example a top marginal tax rate of 70 per cent for income above 10 times the median income, a top marginal tax rate of 10 per cent on all personal net wealth (excluding primary residence) that is above 100 times the median wealth, and of 90 per cent for all inheritances that are above 100 times the median wealth.

The empirical evidence summarized in Section 2 indicates that the effects that can come from a wage-led recovery on growth and hence employment are positive, however they are also modest in magnitude. Wage-led growth is not a magic bullet to solve all the ills of our current economic model and secular stagnation. For sustainable and egalitarian development, we need to mobilize all of the tools of economic policy and in particular public spending with an aim to achieve full employment, ecological sustainability, and equality. This brings a synchronization of wage policy, fiscal policy and industrial policy coordination to the core of economic policy.

A properly designed industrial policy, along with stimulated demand and regulation of finance and corporate governance is required to reinstate the missing link between private investments and profits. But a crucial question is also to redefine the role of public investment in socially much-needed areas, notably two in particular: ecological investments and social infrastructure.

Any progressive way out of secular stagnation should take the climate change and the urgency to limit the carbon emissions seriously into account. Growth without considering the impact on ecology is not a sustainable policy. Ecological sustainability requires a shift in the composition of aggregate demand towards long-term green investments, which in turn calls for an active public investment policy. Private profit motive is insufficient to mobilize resources in the right direction in the right time-frame. Public investment, in green industries like renewable energy, public transport and housing are essential to meet emissions targets to address the ecological crisis. However, policy design should also take into account that any public green investment has quantitatively lower than the expected effects on carbon emissions, because of the macroeconomic rebound effect, that is, any green public investment increases income, which increases spending, which, in turn, increases carbon emissions. Green public investments are still likely to decrease carbon emissions but the important question is how much public spending we need in order to avoid extreme global warming. ${ }^{4}$

Second, public spending in health, education, childcare and elderly care (Onaran 2016b) is at present defined as current spending, although it should be adequately redefined as capital spending in people. These public services are currently provided inadequately by the private sector based on profit motive, and the deficit in this field is currently provided by unpaid invisible female labour. The need for social infrastructure is not sufficiently met under the present circumstances, with inadequately low public spending in this field; private providers fill in the gap by supplying these services either at very low wages (to ensure an adequate profit) or as luxury services for the rich, and a large part is provided via invisible unpaid female labour within the gendered division of labour at home. To avoid this care deficit, a rise in spending in social infrastructure by the state or by non-profit/community organizations is required. Greater public provision of social infrastructure would create employment in labour-intensive social services, and be a vehicle for generating full employment with lower rates of growth - a target more consistent with low carbon emissions.

This could also hit another target, namely increasing female labour force participation rates via socializing the invisible and unpaid care work done by women. Ilkkaracan

4. I am grateful to Yannis Dafermos for this comment. 
(2013) has called these purple jobs. ${ }^{5}$ However, these jobs need to be made attractive to both men and women by improving pay and working conditions in these industries. A new orientation of policies towards creating high-skilled, decent jobs in the social sector should be promoted instead of the current reliance on low-pay service jobs and weak labour unions. Such policies would put gender equality in pay and employment at the heart of a wage-led development strategy. However, if women are concentrated in the types of paid work where the prospect of higher wages does not exist, these policies may still be insufficient to significantly improve women's incomes. Wage policies should reflect the added value of social infrastructure for society, and should gradually target the problem of occupational segregation. This implies a clear break from current policies and the imposing of pay freezes on public sector workers, who are predominantly women.

Finally, a key policy measure to maintain full employment along with low carbon emissions and a more equal income distribution is a substantial shortening of working time in parallel with the historical growth in productivity (Onaran 2015; 2016b). Reduction in weekly working hours should take place without loss of wages, in particular in the case of low/median wage earners, which means an increase in hourly wages as well as in the wage share. Again, this is not unrealistic given historical trends - compared to the nineteenth century we are all working part-time today. The implications of shorter working hours for equality are twofold. First, shorter hours with wage compensation only for lower wage earners will imply a narrowing of gender wage gaps. Second, a proper shortening of working hours should help address daily care responsibilities and enable a more equal work/life balance based on gender equality in the division of labour in the household, for example by requiring shorter daily working hours as opposed to more holidays or longer weekends. Overall, shorter working time with wage compensation is likely to lead to a substantial restructuring of the economy.

\section{CONCLUSION}

This paper summarizes two main findings in the post-Keynesian literature regarding the linkages between financialization, income distribution, accumulation and productivity. First, at the core of secular stagnation lies the missing link between profits and investment. Second, rising inequality and financialization have been the main reasons for this missing link and hence the major brakes on capital accumulation and growth.

The empirical evidence regarding the vicious circle of financialization, rising inequality, and slowdown in accumulation and productivity hints at alternative progressive policies based on a coordinated policy mix of equality-led development and public investment. A crucial issue is how a public investment programme could be financed in practice. Yet if fiscal multipliers are high enough, fiscal expansion could generate the tax revenues to eventually reduce the public debt-to-GDP ratio. Hence, governments should not start with the budget deficit as the aim of policy but, to rephrase Keynes for our times, should focus on taking care of full employment, decent pay for women and men, equality, and ecological sustainability, and the budget will take care of itself.

5. 'Purple' refers to the symbolic colour of feminism. 


\section{REFERENCES}

Alesina, A., Perotti, R. (1996): Income distribution, political instability and investment, in: European Economic Review, 40, 1203-1228.

Alesina, A., Rodrik, D. (1994): Distributive politics and economic growth, in: The Quarterly Journal of Economics, 109(2), 465-490.

Berg, A., Ostry, J., Zettelmeyer, J. (2012): What makes growth sustained?, in: Journal of Development Economics, 98(2), 149-166.

Cordonnier, L., Van de Velde, F. (2015): The demands of finance and the glass ceiling of profit without investment, in: Cambridge Journal of Economics, 39(3), 871-885.

Dallery, T. (2009): Post-Keynesian theories of the firm under financialization, in: Review of Radical Political Economics, 41(4), 492-515.

Decressin, J., Espinoza, R.A., Halikias, I., Leigh, D., Loungani, P., Medas, P.A., Mursula, S., Schindler, M., Spilimbergo, A., Xu, T. (2015): Wage moderation in crises: policy considerations and applications to the euro area, Staff Discussion Notes No 15/22, Washington, DC: International Monetary Fund.

Epstein, G.A. (2005): Introduction: financialization and the world economy, in: Epstein G.A. (ed.), Financialization and the World Economy, Cheltenham, UK and Northampton, MA: Edward Elgar, 3-16.

EC (European Commission) (2006): Time to move up a gear: the new partnership for jobs and growth, URL: http://ec.europa.eu/growthandjobs/pdf/illustrated-version_en.pdf.

EC (European Commission) (2013): Labour costs pass-through, profits and rebalancing in vulnerable member states, in: Quarterly Report on the Euro Area, 12(3), URL: http://ec.europa.eu/economy_ finance/publications/qr_euro_area/2013/qrea3_en.htm

Foerster, M., Cingano, F. (2014): Trends in Income Inequality and its Impact on Economic Growth, Paris: OECD.

Galor, O., Zeira, J. (1993): Income distribution and macroeconomics, in: The Review of Economic Studies, 60(1), 35-52.

Gechert, S. (2013): What fiscal policy is most effective? A meta regression analysis, IMK working paper 117.

Goda, T., Onaran, Ö., Stockhammer, E. (2016): The role of income inequality and wealth concentration in the recent crisis, in: Development and Change, forthcoming.

Hein, E. (2013): Finance-dominated capitalism and re-distribution of income: a Kaleckian perspective, in: Cambridge Journal of Economics, doi: 10.1093/cje/bet038.

Hein, E., Mundt, M. (2012): Financialisation and the requirements and potentials for wage-led recovery: a review focussing on the G20, Conditions of work and employment series, No 37, Geneva: ILO.

Hein, E., van Treeck, T. (2008): Financialisation in Post-Keynesian models of distribution and growth: a systematic review, Working paper no 10, IMK at the Hans Boeckler Foundation, Macroeconomic Policy Institute.

Hein, E., Vogel, L. (2008): Distribution and growth reconsidered: empirical results for six OECD countries, in: Cambridge Journal of Economics, 32, 479-511.

Ilkkaracan, I. (2013): The purple economy: a call for a new economic order beyond the green, in: Röhr, U., van Heemstra, C. (ed.), Sustainable Economy and Green Growth: Who Cares?, Berlin: LIFE e.V./German Federal Ministry for the Environment, 32-37.

ILO (2012): Global wage report, Geneva: ILO.

IMF (2009): Global economic policies and prospects, Note by the Staff of the International Monetary Fund, G20 Meeting of the Ministers and Central Bank Governors, 13-14 March, London.

Naastepad, C.W.M., Storm, S. (2006-2007): OECD demand regimes (1960-2000), in: Journal of Post-Keynesian Economics, 29, 213-248.

Onaran, Ö. (2014): The case for a coordinated policy mix of wage-led recovery and public investment in the G20, URL: http://www.tuac.org/en/public/e-docs/00/00/0F/17/document_news.phtml.

Onaran, Ö. (2015): State and the economy: a strategy for wage-led development, Greenwich Papers in Political Economy, No GPERC24, London: University of Greenwich. 
Onaran, Ö. (2016a): The role of gender equality in an equality-led sustainable development strategy, in: Bargawi, H., Cozzi, G., Himmelweit S. (eds), Lives After Austerity: Gendered Impacts and Sustainable Alternatives for Europe, London: Routledge, forthcoming.

Onaran, Ö. (2016b): Wage- versus profit-led growth in the context of globalization and public spending: the political aspects of wage-led recovery, in: Review of Keynesian Economics, forthcoming.

Onaran, Ö., Bösch, V. (2014): The effect of globalization on the distribution of taxes and social expenditures in Europe: do welfare state regimes matter?, in: Environment and Planning A, 46(2), 373-397.

Onaran, Ö., Galanis, G. (2014): Income distribution and growth: a global model, in: Environment and Planning $A$, 46(10), 2489-2513.

Onaran, Ö., Obst, T. (2015): Wage-led growth in the EU15 Member States: the effects of income distribution on growth, investment, trade balance, and inflation, Greenwich Papers in Political Economy, No GPERC28, London: University of Greenwich.

Onaran, Ö., Stockhammer, E. (2005): Two different export-oriented growth strategies: accumulation and distribution a la Turca and a la South Korea, in: Emerging Markets Finance and Trade, 41(1), 65-89.

Onaran, Ö., Stockhammer, E. (2016): Policies for wage-led growth in Europe, Report for the Foundation of European Progressive Studies, URL: http://www.feps-europe.eu/assets/ea50ecd6-6ff54922-be9a-ffb770f8664e/policies-wage-led-up-growth-europepdf.pdf.

Onaran, Ö., Stockhammer, E., Grafl, L. (2011): The finance-dominated growth regime, distribution, and aggregate demand in the US, in: Cambridge Journal of Economics, 35(4), 637-661.

Onaran, Ö., Guschanski, A., Meadway, J., Martin, A. (2015), Working for the economy: the economic case for trade unions, Greenwich Papers in Political Economy, No GPERC32, London: University of Greenwich.

Orhangazi, Ô. (2008): Financialisation and capital accumulation in the non-financial corporate sector: a theoretical and empirical investigation on the US economy, 1973-2003, in: Cambridge Journal of Economics, 32(6), 863-886.

Persson, T., Tabellini, G. (1994): Is inequality harmful for growth?, in: The American Economic Review, 84(3), 600-621.

Rotta, T. (2015), Productive stagnation and unproductive accumulation: an econometric analysis of the United States, Greenwich Papers in Political Economy, No GPERC09, London: University of Greenwich.

Stockhammer, E. (2004): Financialisation and the slowdown of accumulation, in: Cambridge Journal of Economics, 28(5), 719-741.

Stockhammer, E. (2006): Shareholder value orientation and the investment-profit puzzle, in: Journal of Post Keynesian Economics, 28(2), 193-215.

Stockhammer, E. (2016): Determinants of the wage share: a panel analysis of advanced and developing economies, in: British Journal of Industrial Relations, forthcoming.

Stockhammer, E., Onaran, Ö. (2004): Accumulation, distribution and employment: a structural VAR approach to a Kaleckian macro-model, in: Structural Change and Economic Dynamics, 15, 421-447.

Stockhammer, E., Onaran, Ö., Ederer, S. (2009): Functional income distribution and aggregate demand in the Euro area, in: Cambridge Journal of Economics, 33(1), 139-159.

Tori, D., Onaran, Ö. (2015): The effects of financialization on investment: evidence from firm-level data for the UK, Greenwich Papers in Political Economy, No GPERC17, London: University of Greenwich.

Tori, D., Onaran, Ö. (2016): Financialization and the global race to the bottom in accumulation, UNCTAD Project report, unpublished background paper.

van Treeck, T. (2008): Reconsidering the investment-profit nexus in finance-led economies: an ARDL-based approach, in: Metroeconomica, 59(3), 371-404. 